\title{
Colin McCahon and the Visible Mystery of Painting
}

\author{
LAURENCE SIMMONS
}

“. . . within religion itself art is not religious." (Jean-Luc Nancy, The Muses)

"Everything is capable of becoming a sign of revelation. What is made available to us in revelation is not the essence of God as it subsists independently of our existence, but his relationship to us and our relationship to him." (Martin Buber, Nachlese)

\begin{abstract}
This essay brings together two paintings that on the surface seem to have very little in common: one dates from 1528-29 (The Visitation by the Italian late Renaissance painter Jacopo Carucci, better known as Pontormo after his birthplace), the other from 1968 (Visible Mysteries no. 8 by Colin McCahon). They are brought together here because they share the same subject matter: the central Catholic doctrine of the Incarnation, the mystery of God's word becoming flesh, and the belief that divine and human natures are united. These two paintings can, in both similar and different ways, teach us something about the visible mystery that is painting.
\end{abstract}

Much has been made and not made of Colin McCahon's engagement with religion. From Tony Green, who "wearied of it" and declared it "unfortunate that McCahon used so many religious texts in his paintings, since this attracts the most careless of assumptions: that the paintings themselves are sanctified as a result"; to, most recently, Thomas Crow, who proposes that McCahon reinstates a "missing theology" to contemporary painting. ${ }^{1}$ To introduce again the topic of Colin McCahon's painting and religion I am going to talk about two paintings that on the surface seem to have very little in common: one dates from 1528-29, the other from 1968, a difference of some 440 years; one is figurative, the other we might describe as symbolic; one is astonishing for the brightness and acidity of its colours, the palette of the other is more sombre shades of black, white and grey; both are parts of a number or series of works done by their artists on the same subject matter. There is no suggestion that the later painter knew of or even saw the painting by the earlier painter, perhaps not even in reproduction. Why then, you might ask, bring them together? Because, as I shall attempt to argue, both these paintings are about "meeting" and "bringing together," and perhaps more importantly, they share the same structure: that of the Incarnation, the formula by which God makes himself human and the mystery of God's word becomes flesh. They can, in both similar and different ways, I believe, teach us something about the place of religion within art.

\section{Pontormo}

My first painting is the Visitation (1528-29), by the Italian late-Renaissance painter Jacopo Carucci (1494-1556), better known as Pontormo after his birthplace in Tuscany, found in the Church of San Michele and San Francesco in Carmignano, twenty kilometres west of Florence. Pontormo, after his rediscovery in the early twentieth century, is now regarded as one of the major representatives of early Florentine Mannerism. ${ }^{2}$ This painting has recently been restored and was the subject of a small exhibition in the Palazzo Pitti in Florence in 2018 that has since travelled to the Pierpont Morgan Library in New York and the Getty Center in Los Angeles. ${ }^{3}$ 


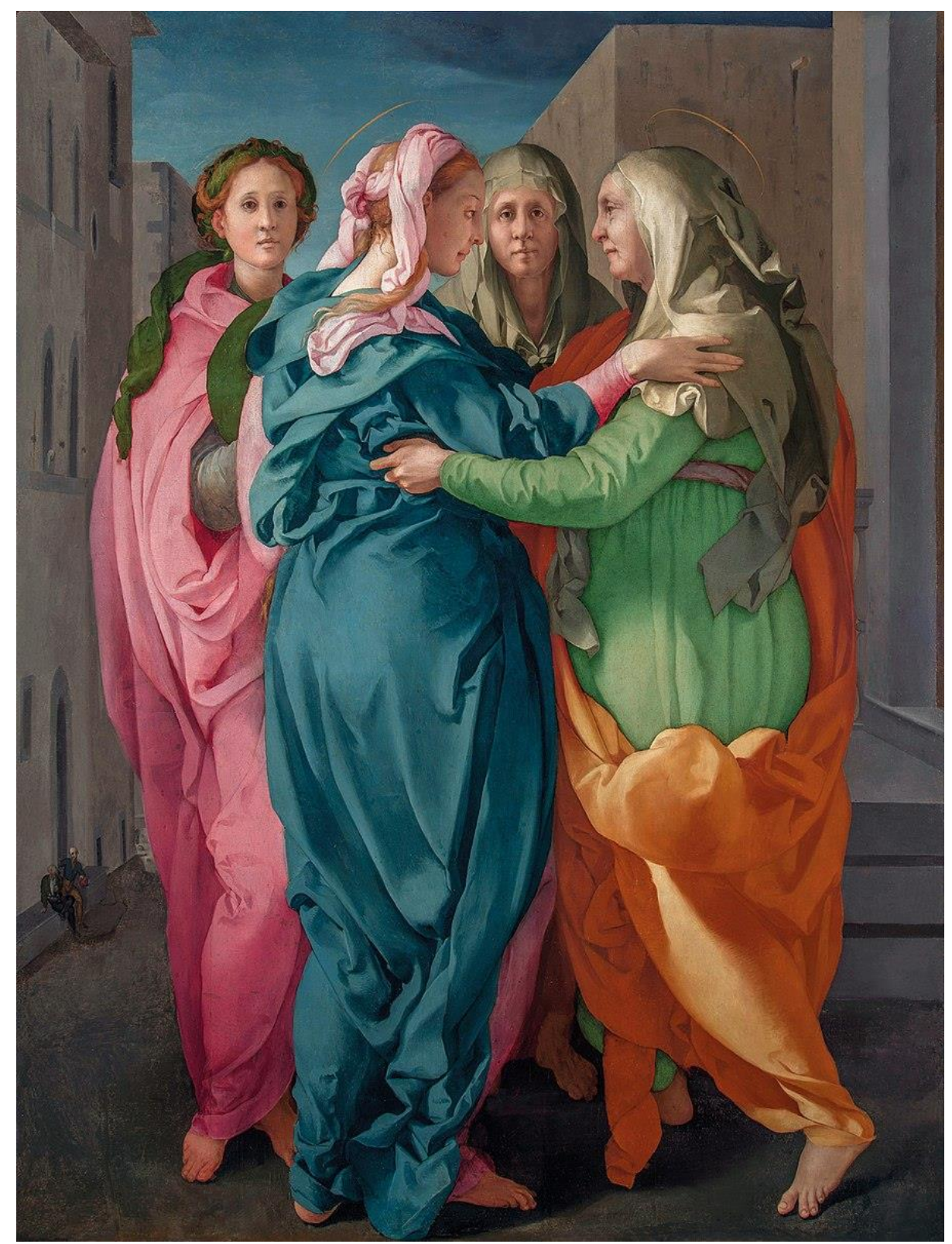

Figure 1. Pontormo, Visitation, 1528-29. Oil on panel. Church of San Michele and San Francesco, Carmignano.

The painting centres on a moment or moments before the birth of Christ, what the Catholic doctrine calls the Advent. It centres, we might say, on the birth of the birth. It is a scene that has been perhaps of interest more to painters than it has to theologians. As a scene in painting it is referred to as a "visitation"; it is also a moment of extreme emotion, surprise, even strangeness when compared to the moments before and after it: the Annunciation and the actual Nativity. Here is the moment: after having received the angel of the Annunciation herself, Mary learns that her cousin Elizabeth has fallen pregnant in a way that her advanced age seemed to prohibit. And already at her own second month of pregnancy Mary visits Elizabeth. ${ }^{4}$ No impetus or cause for this visit is given; perhaps it is just the desire to share a common state, to pass on practical knowledge, or to reaffirm by duplication the nature of the miracle involved in both cases. The word "visitation" (visitatio) in ecclesiastical Latin is, however, not a simple visit: it represents a practice to realise, to examine and prove, or allow something to be proven. ${ }^{5}$ A sort of pregnancy test, one might say. 
In fact, in the biblical account when Mary - on our left in Pontormo's painting - arrives, Elizabeth exclaims out loud: "Blessed are you among women, and blessed is the fruit of your womb. And why has this happened to me, that the Mother of my Lord comes to me? For as soon as I heard the sound of your greeting, the child in my womb leaped for joy." "The scene is described in Luke (Luke 1: 39-45), and Luke has been understood as "the evangelist of childhood, who is also the patron saint of painters because according to his legend he painted Mary's portrait." Elizabeth's son will be John the Baptist, the precursor of Christ and who in the obscurity of Elizabeth's womb is believed, as the verse of Luke attests, to have heard the voice of Mary, pregnant with Christ. Here the two wombs come together, bump to bump. ${ }^{8}$ But there is no mention in the biblical text of any physical contact between the two women. The scene of the visitation was popular in the visual arts, being depicted as part of the nativity cycle; for example, Giotto's Visitation in the Cappella Scrovegni depicts the two women embracing, and emphasises the intensity of the encounter through the exchange of glances.

Pontormo's scene, then, is exquisitely spiritual and mystical, but it is also one that deals directly with the question of vision. We focus immediately on the crossing of gazes; the two women gaze intently into each other's eyes. Only two eyes, note (only one visible on each profile), each one seeing and being moved by what cannot be seen but which does not cease to move. Two eyes that mirror our own and are somehow repeated, we feel, in those of the servant at the centre who fixes us with her gaze, and, as if we did not get the point, by the servant to our left who fixes us again. Now we have six visible eyes but really eight, our two that are there again in the two eyes we do not see of the protagonists, eyes that are hidden. The painting is also mysterious because of the presence of the two figures who gaze out at the viewer who are also not mentioned in the Gospel of Luke. There is no doubt as to the function of these two women, how their gazes, looking past us, arrest us and draw us into the fictional space inhabited by the sacred figures of Mary and Elizabeth. But who are these women at the rear? There have been various hypotheses: mere servants (they do not possess haloes), angels without wings, Mary and Elizabeth themselves rotated ninety degrees to thus give us two different viewpoints, frontal instead of in profile. Angels were supposedly without gender and that is not the case here, so we can dispatch that hypothesis quickly. The most powerful arguments for rotation are the similarity in appearance of the two faces of the figures and the inversion of colours of their garments: the figure behind Mary wears pink drapery over a green dress, whereas Mary wears the traditional blue cloak over a pink garment; Saint Elizabeth's dress is green under her orange cloak while the woman behind has a green outer garment. But perhaps the most convincing argument remains that these figures are female attendants. The two servants, each of whom is a version of her mistress in terms of her face, her head covering and her age, transfer their mistresses' gazes frontally. ${ }^{9}$ Perhaps more important than who they were is how they function. The frontal gaze of the subject who stares out and back at us, a gaze that seeks our own, seems to await our gaze, as a portrait often does. It is as if, then, the painting itself were awaiting its "visitation" from you and I. A visitor like you and I who would know how to see the hidden subject of the painting, that which is hidden within the wombs of its subjects. Visitors who might know how to see the invisible. 


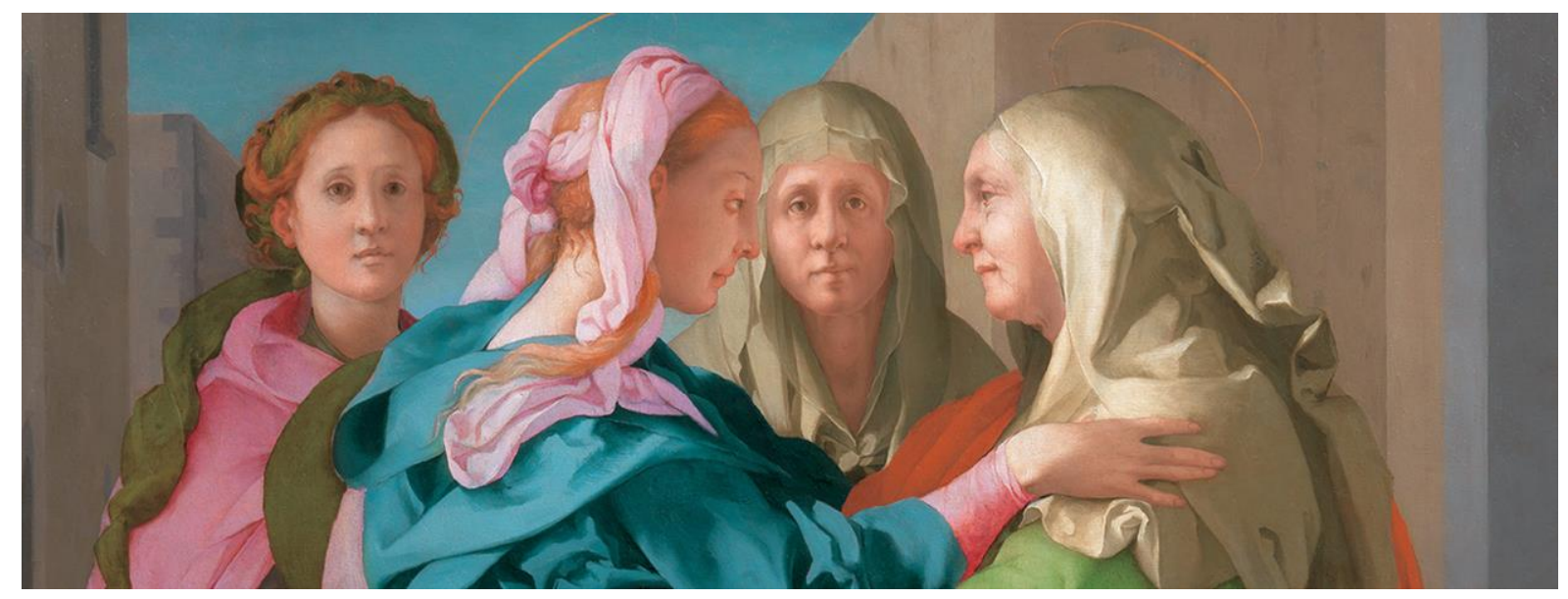

Figure 2. Detail, Pontormo, Visitation, 1528-29. Oil on panel.

Church of San Michele and San Francesco, Carmignano.

There is something more if we look hard. We almost need to come up to touch the painting, and we have already noted that what we hear through the "touch of the voice" but cannot see is the child in the womb who leaps for joy. Barely discernible, deliberately placed at a distance and in partial shadow are two figures, or the barest hints of figures. In this painting, which works at breaking down perspectival space, the opening of space off to the left is a street, and the two figures are engaged in conversation sitting on a typically Florentine stone bench, a panca. The figures are two men, with the appearance of ordinary Florentines, one of whom, according to Jean-Luc Nancy, holds a knife and a round loaf of bread, the other a bottle. ${ }^{10}$ One figure looks at the other in a smaller version that echoes the central scene of exchanged gazes. But (and is this intentional?) they are barely visible, and yet necessarily there, embedded in the ground of the painting like the two children whose presence we feel but cannot see embedded in the wombs of their mothers. These figures are likely to represent Joseph and Zechariah, the husbands of the pregnant cousins. With the reference to bread and the wine-if that is what it is - the Incarnation is doubly marked by Pontormo in a hidden form, where the allusion is to the body and the blood of Christ shared out among the disciples at the Last Supper, a gesture that Jesus asks to be repeated "in memory" of him (Luke 22: 19), a request that is fulfilled at the ceremony of the Eucharist. Pontormo has given us a double visible mystery. For the Catholic Church, the Incarnation is the most important mystery, the central doctrine of God's word becoming flesh, the belief that divine and human natures are united. 


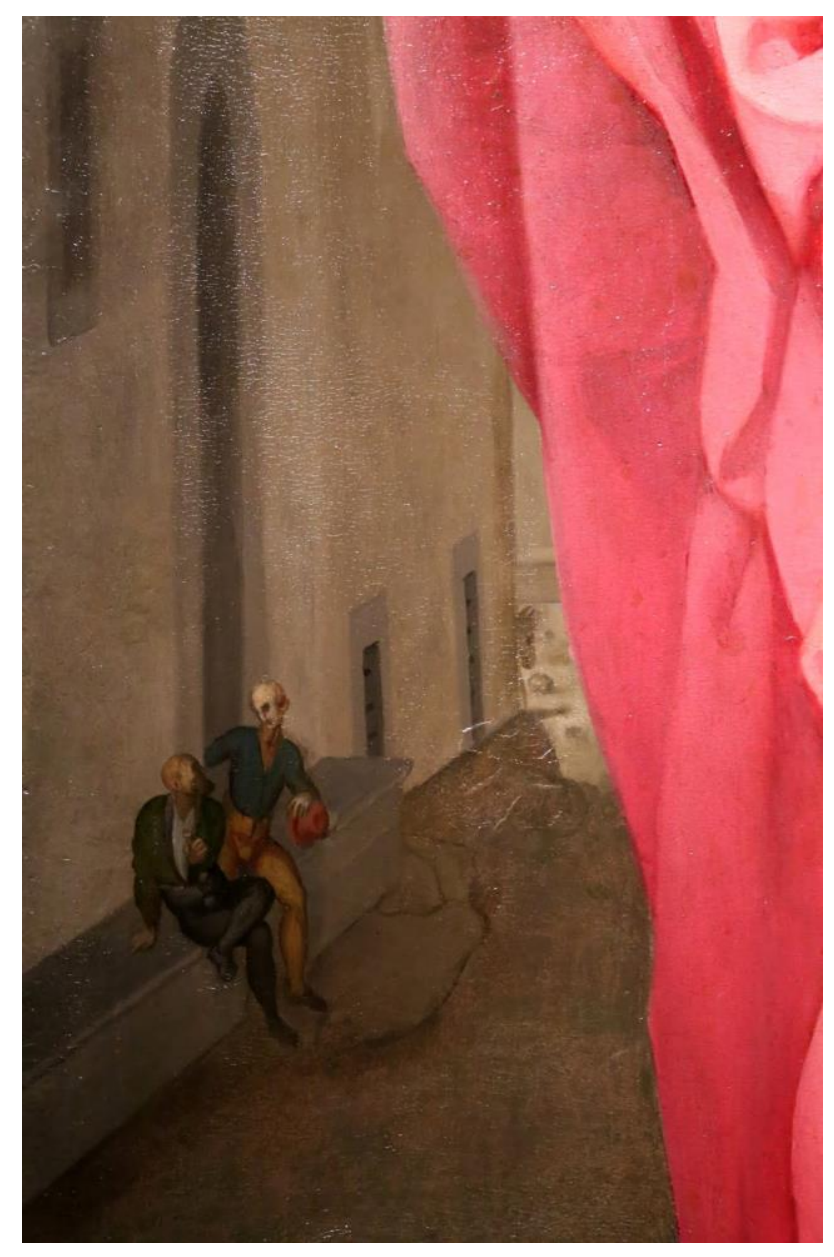

Figure 3. Detail, Pontormo, Visitation, 1528-29. Oil on panel.

Church of San Michele and San Francesco, Carmignano.

We are therefore dealing with a challenge for painting, one of the purest challenges in which it must render visible an invisible message. It must convey how the sense of the invisible can be portrayed in the visible. The question we ask ourselves, as if following the words of Elizabeth, is how do we see the invisible? How does it leap out at us? Where is its "bump"? And with what joy do we experience this? Pontormo is inviting us to think of a real and hidden presence at the heart of his painting. The mystery of Incarnation and conception perhaps helps explain the very brilliance of the painting, where everything depends upon a superabundance, a supervisibility of phosphorescent colour, as if waiting to burst forth. The brilliance of the painting's colours is its force, a force that would form its substance and yet conceal its mystery, just as the wombs of the two women conceal the fruits of their two mysterious conceptions.

But we might stop and ask here, what exactly is "incarnation"? How does the structure of incarnation work? And in what sense can we understand Pontormo's work as a form of incarnation? Thinking through the Latin phrase verbum caro factum est ("And the Word became flesh") (John 1: 14), ${ }^{11}$ Jean-Luc Nancy demonstrates that there are two interpretations of this phrase, and that each excludes the other. In one sense, the flesh, the body, caro, gives rise to the Word, whereas the other sense prioritises the Word $(\log o s)$ and gives rise to the flesh. Either the flesh opens for the Word or the Word inaugurates and sanctifies the flesh. ${ }^{12}$ And in all of this there is an absolutely different relation between the spectator and Pontormo's art than the usual aesthetically distanced, self-reflective one: this one is performative, engaged - "religious" in the sense of religio, "tying together." And it is for exactly this reason 
that Pontormo's work, strikingly, anachronistically, is not only religious in subject matter butmore importantly_religious in its address.

The term "incarnation," as Jean-Luc Nancy has argued and I noted above, can be understood in two ways: it can refer to the entering of an incorporeal entity into a body, and implies that the body is a place occupied by an invisible soul or spirit. This is the body as representation, a sensible manifestation of a spirit that cannot be represented. Incarnation in the theological sense of the word refers to the idea that God became - or rather, was engendered as - flesh, resulting in one person with two heterogeneous natures. In this second sense, Nancy suggests, the Christian body is not a material exterior enveloping a soul but a spirit moving out of itself, out of its pure identity. According to Nancy's interpretation, the incarnate God is not a visible representation of an invisible entity but a God whose gesture consists in the alienation of himself, an emptying out or kenosis. ${ }^{13}$ Thus, the body of the Incarnation is not a representation or imitation that supposes resemblance but becomes the place of the alienation of God from himself. The body of the Incarnation is not created in the image of God, but in the image of an absence of a model, and thus the created world, the world of the painting, does not imitate anything but the inimitable.

The phrase pronounced at the Eucharist - Hoc est enim corpus meum, "For this is my body"commemorates the Incarnation which is announced by a bodiless angel; similarly, the Eucharist makes present here and now a something (God, the Absolute) that cannot be seen or sensed. The presentation, this Hoc est enim ("For this is"), dissipates all our doubts regarding the world of appearances by presenting "the thing itself," not as idea but as body, that is, as an incarnate sense. Incarnation is thus not the materialisation of an invisible idea or spirit; it is the irreducible ambiguity of all bodies as flesh - matter and spirit in the same place. Both the "visitation" and the "transubstantiation" of the body of Christ into the bread and wine of a "communion" represent two intensifications, two "re-visitations," of the Incarnation, creating a visible image of the invisible, the manifestation of that which does not manifest itself. ${ }^{14}$ On the one hand, giving the man-god a provenance in the human body, the body of a woman (Pontormo); and, on the other hand, in giving the divine body the capacity to change again into inorganic matter, bread and wine (the small figures depicted by Pontormo).

\section{McCahon}

And this will be my point of connection, my "meeting" with my second painting, a painting as already noted distant in time and place, and seemingly perhaps in theme too: Colin McCahon's Visible Mysteries no. 8 (1968). Nevertheless, I believe that in both paintings we encounter the same structure: that of the Incarnation. Now I want to see if I can explore a little further this second version of the structure in a series of McCahon works, the Visible Mysteries, a series of eight paintings from 1968. ${ }^{15}$ In Visible Mysteries, McCahon used two different formats: three of the works are in landscape format and are confined in colour to black and white; and the other five are in vertical (or "portrait") format, and are more varied in imagery and colour. The title of the series comes from a quotation in the bottom left corner and is common to all eight works: "GRANT THAT WHAT WE HAVE RECEIVED / IN VISIBLE MYSTERIES / WE MAY RECEIVE IN ITS INVISIBLE EFFECT." These words are from a post-communion prayer used on Ascension Thursday, which McCahon took from the New Sunday Missal, a Catholic liturgical calendar he owned. 


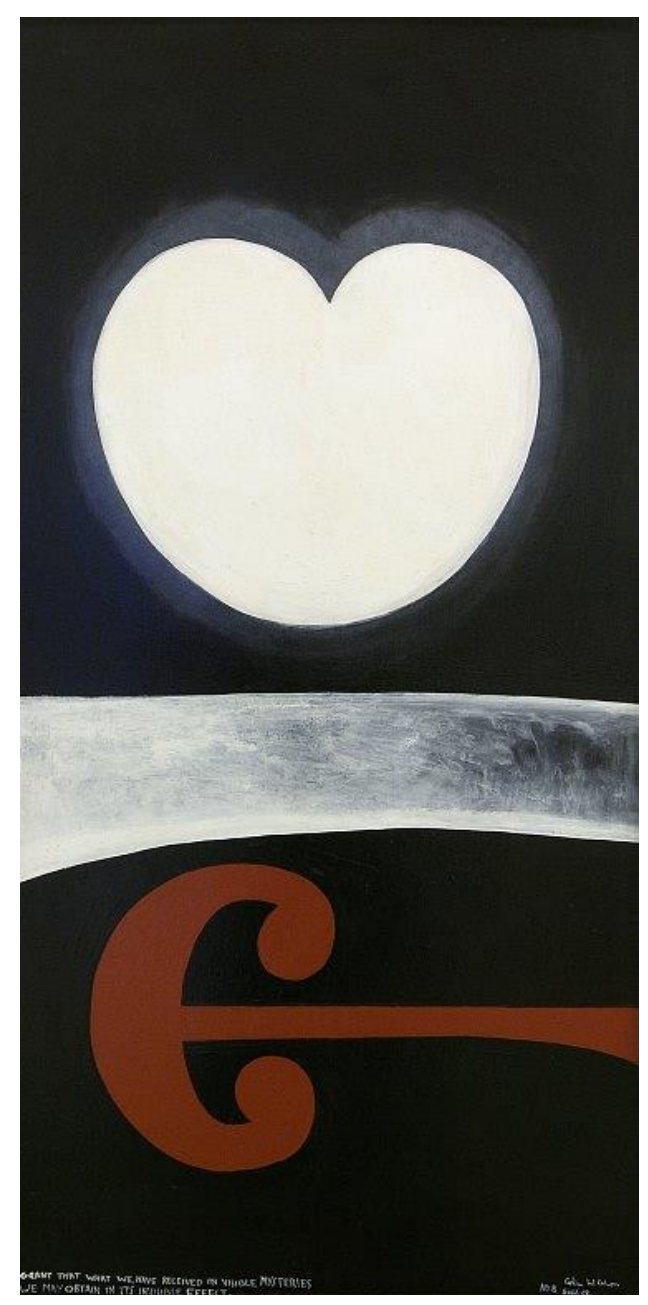

Figure 4. Colin McCahon, Visible Mysteries no. 8, 1968. Synthetic polymer paint on hardboard. Chartwell Collection, Auckland Art Gallery Toi o Tāmaki.

These are works that are undoubtedly influenced by McCahon's long engagement with the Catholic Church, and directly follow a commission he completed for stained glass windows at the Convent of Our Lady of the Missions, Remuera, a commission during which McCahon engaged in extensive dialogue with the then Archbishop Liston about certain doctrines of the Catholic Church. ${ }^{16}$ The now detached main convent east window has been restored and has just been on exhibition in the Auckland Art Gallery. ${ }^{17}$ Panels 9-a chalice of wine and the name in Greek for Jesus IHSUS - and 10-wheat and grapes indicating symbolically the Holy Communion (bread and wine) — refer to the transubstantiation of the body of Christ mentioned a moment ago and which is, of course, one of the rituals that distinguish the Catholic Church from the Protestant Church. It is the mystery of the Incarnation as represented in the ceremony of the Holy Communion during church service, in which parishioners drink what is said to be Christ's blood and eat bread as Christ's flesh. It is undoubtedly as some kind of painterly equivalent to this ceremony that McCahon painted Visible Mysteries. ${ }^{18}$ 


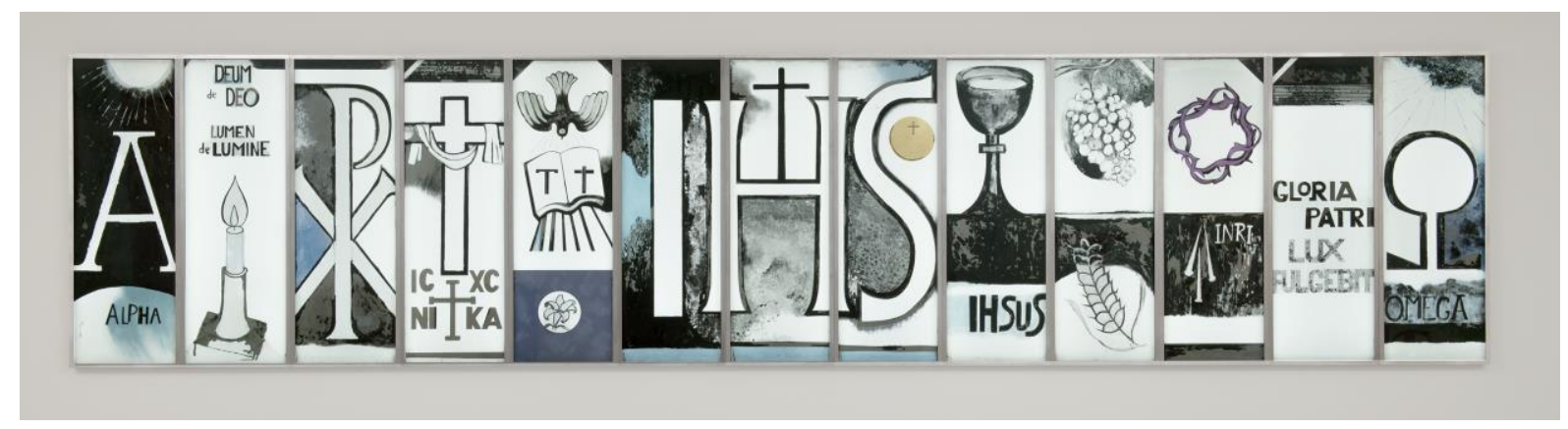

Figure 5. Detail, Colin McCahon and Richard Killeen, [East Window: Convent Chapel of the Sisters of our Lady of the Missions, Auckland], 1965-66. Alkyd on glass. Auckland Art Gallery Toi o

Tāmaki, gift of the Chapel of the Sisters of Our Lady of the Missions, Auckland.

In this series, a number of common objects of the church are painted with crude, reduced, barely identifying marks in white against a black background with the fewest or most economical means. Unlike Pontormo, McCahon does not depict the human form, instead using objects as symbols. The objects obviously retain religious, symbolic associations: the table of the Last Supper becoming the altar where the Communion service takes place, the chalice that contains the wine, the heart that is the sacred heart of Jesus. In No. 4 the white symbolic heart of Christ (also a communion wafer?) hovers above the altar, its blood of redemption pouring from the heart into a chalice placed on the altar (curving like a McCahon waterfall). In No. 1 the format has become landscape and the rudimentary geometric building blocks of the altar predominate. In No. 5 the common Christogram his, based on the first three letters of "Jesus" in Greek, enhances the sense of uncompromising abstraction. In No. 6 the altar has become abstracted to just an edge and corner, a white heart looming above it. In No. 8 the slab of the altar has become a wide curved line across the centre of the composition (perhaps the light of the sky) with the white heart above and a blood red koru form below. As with the technique of including a local reference in the early religious landscapes, the presence of this symbol firmly locates the mystery of the Eucharist in New Zealand and by extension the metaphor of the body of Christ as representative of the Christian community here. The red koru (by this time McCahon had seen and responded to Gordon Walters 1966 exhibition at the New Vision Gallery in Auckland) can be read as Christ's blood spilt on the Cross, or the blood spilt when Ranginui (sky father) and Papatūānuku (earth mother) were separated by Tānemahuta, or the life force of the land. But the true "visible mystery," the true transubstantiation, takes place in a sense elsewhere, before this. For to speak of "visible mysteries" is to accept that certain phenomena cannot be transformed into representable objects. It is the very seeing of these material scraps of paint as objects, as a chalice, altarpiece, or heart that is the exact transubstantiation - the passing of flesh into spirit - that is the theme at stake throughout this series and all of McCahon's work. 


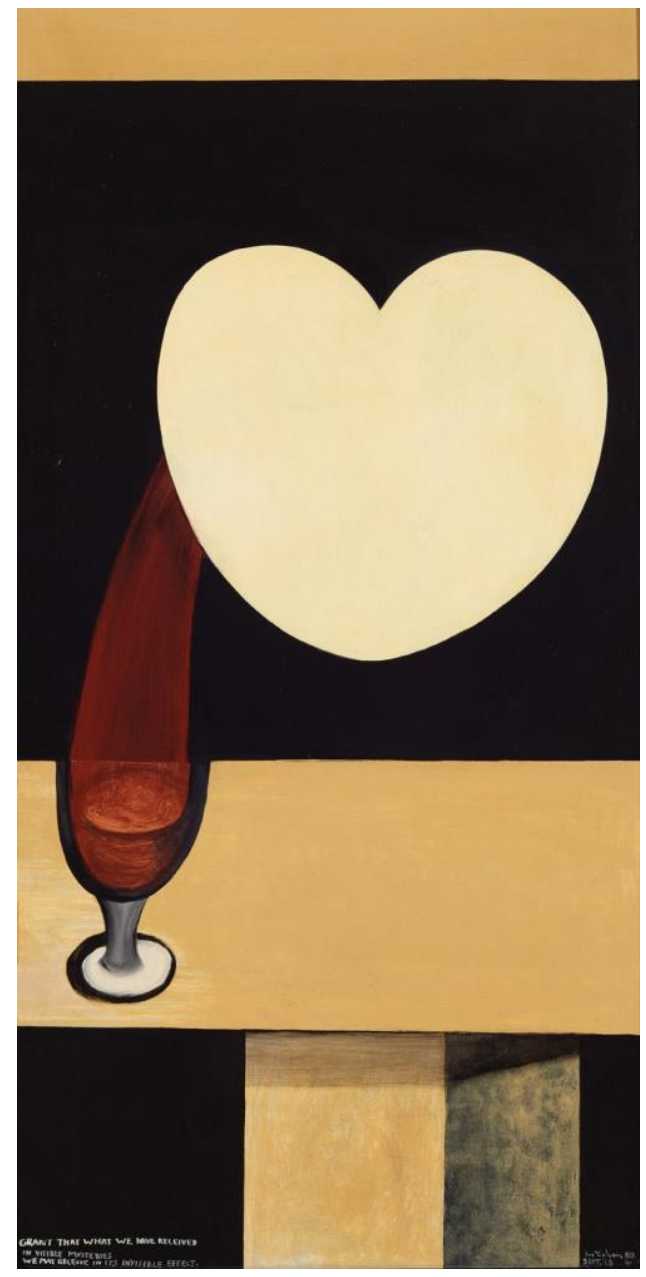

Figure 6. Colin McCahon, Visible Mysteries no. 4, 1968. Synthetic polymer paint on hardboard. Private collection.

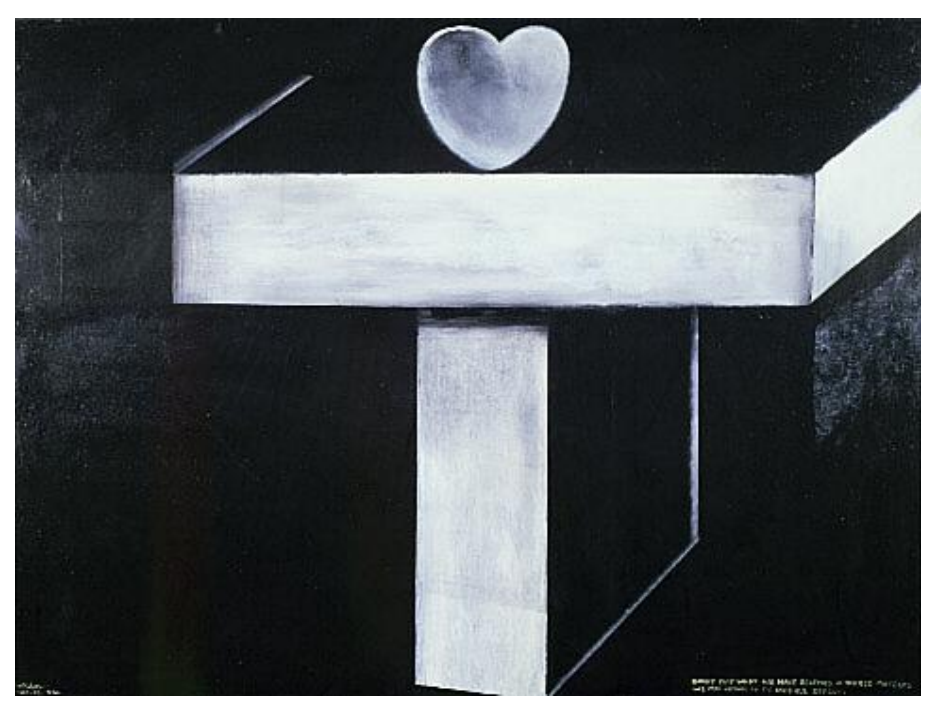

Figure 7. Colin McCahon, Visible Mysteries no. 1, 1968. Synthetic polymer paint on hardboard. Auckland Art Gallery Toi o Tāmaki. 
McCahon's interest in the Incarnation and the Eucharist is part of the structure of prophecy that guides his work. ${ }^{19}$ Prophecy is popularly understood as the stating of a factual prediction that is proven either wrong or right by subsequent events. So prophecy has a temporal limit: in a way, it is no longer a prophecy (whether proven wrong or right) after the event it speaks of. But authentic prophecies - like that of the birth or the second coming of Christ - are not like this. They do not come to an end. They live forever. Indeed, they are the only things that do not come to an end. They are neither refuted by what goes against them, or even more surprisingly not confirmed - or let us say exhausted - by what appears to confirm them. In fact, the real aim of prophecy is not to be right or wrong, not to make factual predictions about the world in advance. Rather, true prophecy simply opens up a kind of space in which events can be seen, events which retrospectively (not prospectively) confirm the prophecy. That is, it is not that prophecy is either confirmed or denied by events, but events are seen in the light of prophecy. McCahon is looking for an art that is prophetic, that is necessarily true, that passes into the future without ever becoming exhausted. And with the structure of the Incarnation he does this in a strange way because to see or hear the prophecy is to fulfil the prophecy; because the one who sees or hears the prophecy is the prophecy. Again, a prophecy is not a prophecy until it is taken up by another. Indeed, in a way the prophecy is only its being taken up by another. McCahon's work lives on-and this is why all of his work is a form of prophecy, seeks to work in the mode of prophecy - not because it is something stated in advance, some content or style that might potentially pass out of fashion-not because it is anachronistically religious, as some early critics felt-but because it is only what its spectator makes of it. The subject of the work is its very relationship to the spectator. And McCahon's work has the pure emptiness of prophecy, which is the pure materiality of its painterly inscription. Again, to put the two halves together: prophecy, like the Eucharist, is only its singular inscription each time, at once absolutely transcendental, a kind of nothing unable to be realised, appearing inexhaustibly pointed towards the future. It is only ever particular appearances, only the practical actions of events in the world that realise it, confirm it, singularly each time; outside of these it does not exist (for it only exists after these, as it were).

\section{Christian painting}

What do we understand by "Christian painting"? ${ }^{20}$ What did our two painters understand? Certainly, it is not simply the representation of Christian narrative, or stories from the Bible. Christian painting is not just the representation of Christian subject matter. Nor is it simply true that Christianity commissioned and developed its images as an illustrated Bible for the illiterate. Rather it is Christianity, or something of Christianity in or as painting, that makes it painting, that gives birth to painting announcing itself in it and like it, the essential thing of what we call depiction. Christianity, as well as the Christian image, bear all the intensity of the access to the inaccessible, to the presence without presence, the image with no resemblance, and the appearance without image, the non-appearing. We might say that it is both literally and metaphorically here a pregnancy.

Thus painting for Pontormo, and for McCahon, does not merely illustrate religion; rather, the two are engaged in the same self-deconstruction. Whereas art provides the sensible articulation of the internal destabilisation of the religious mode, the unstable core in religion forms an integral part of art, from the Renaissance through to the twentieth century. The proper subject matter of the religious representation or the image becomes the invisibility of God. It is the idea of the Incarnation that forms a central self-deconstructive moment of Christian monotheism. The Incarnation cannot be understood as representation because "Incarnation" in the theological sense of the term refers to the idea that God becomes flesh. Paradoxically, the Incarnation involves the renunciation, at least in part, of the divine nature of Christ. This 
kenotic aspect of the Incarnation defines the Christian body not as a material exteriority enveloping a soul but as the taking place of the withdrawal (kenosis) of God. The body is the place of the alienation of God from himself, and representing it is the material presentation of this alienation, the presentation of absence. Art then does not have representational value; it is a presentation of the open wound of absence. The image does not illustrate an invisible truth; it does not preach a univocal message. On the contrary, it is the presentation of the thing that appears, the presentation of itself; in other words, a "visitation" or an address.

Incarnational images are desire-images since they constitute a paradigm, a matrix of relationships in which the artist - as in the case of Pontormo or McCahon - tries to think himself in the image of his God. Incarnation implies alteration rather than imitation in order to be able to think the drama of the primary resemblance between God and the human, which in turn is a drama that turns around the death of the image of God required by His very Incarnation. So my claim is that the paintings of these two artists do not pretend to be visual translations of Christian stories: that is, they are neither simply narrative nor illustrative, nor even purely symbolic. The painters employ a "nonrepresentational strategy" to translate in pictorial terms the mystery of the Incarnation, which in turn determines the figurative aspect of Christian images - they are almost always corporeal representations (figures for Pontormo; symbolic objects for McCahon). By breaking out of the purely representational economy of the painting, this move highlights the fact that these works have no model and hide no invisibility other than the intensity of their presence. Thus, the religiosity of both Pontormo's and McCahon's paintings is to be found not in its representational or narrative aspect (in fact, we might be bold and suggest that there is no such thing as a "religious image") but in the way they highlight the materiality of their own presence, how they present themselves to their beholders, address themselves by intensifying his or her presence. Precisely this indexical - in other words, presentational (and specifically not representational) - aspect of these paintings is the location of sacred meaning. It is in Visitation and Visible Mysteries that Christian painting indicates what is at stake in Christianity. Insofar as it is a representation of the divine, it must actually abandon the religious mode. By figuring the imageless God, Christian painting figures the metamorphosis of the invisible divine into the intensity of a place that opens itself to presence; a place that, as I have suggested, "presents itself." Painting is thus the place, or rather, the event, the taking place of a self-deconstruction. Such a line of analysis is informed by a radical rethinking of the incarnational formula and displaces the properly religious element in what is generally referred to as Christian art.

Paradoxically, then, what Pontormo and McCahon show us is that true religious art in this sense is necessarily defined by a negative moment, its proper subject is the inaccessibility of God and its task the figuration of that inaccessibility. However, in as much as it is part of the world, material, each painting also presents itself. It is in this sense that it is not religious: the paradox of the representation of the invisible God transforms itself into the self-presentation of the image. Thus the image occupies an aporeitic place with regard to religion by virtue of its impossible task - to figure the invisible - and in so doing it deconstructs religion from within at the same time as it enacts "the religious." Painting cannot be placed in the position of figuring, illustrating or representing the divine. It must invent the visibility of the divine and claim the divine in every image it makes. 
This essay is for Hamish Coney, who first lead me twenty-five years ago to Pontormo's Deposition in the small church of Santa Felicità Oltrarno over the Ponte Vecchio on the south bank of the River Arno in Florence.

${ }^{1}$ Tony Green, "McCahon Made Difficult," Art New Zealand 49 (1988/89): 54. Thomas Crow, "A Way with Words: Practical Religion in the Art of Colin McCahon," in No Idols: The Missing Theology of Art (Sydney: Power Publications, 2017), 55-84.

${ }^{2}$ In the autumn of 1912, the American art historian Frederick Mortimer Clapp discovered Pontormo's Deposition of Christ in the Church of Santa Felicità and became entranced by the artist. In 1916, he published his monograph on Pontormo's work that became the catalyst for renewed interest in the artist.

${ }^{3}$ The list of those who have drawn inspiration from Pontormo includes: Amadeo Modigliani; the filmmaker Pier Paolo Pasolini; and Georg Baselitz and Bill Viola, who showed a large format video work, The Greeting, at the 1995 Venice Biennale inspired by the Visitation. See A. Galansino and K. Perov, eds., Bill Viola: Rinascimento elettronico/Bill Viola Electronic Renaissance, Exhibition catalogue, Florence Palazzo Strozzi, 10 March-23 July 2017 (Florence: Giunti, 2017). My discussion of Pontormo's Visitation is indebted to that of Jean-Luc Nancy, "Visitation: Of Christian Painting," in The Ground of the Image, translated by Jeff Fort (New York: Fordham University Press, 2005), 10825.

${ }^{4}$ The Feast of the Visitation is celebrated on 31 May. Elizabeth would have been more than six months pregnant with John, and Jesus two months incarnate in Mary's womb.

${ }^{5}$ Nancy, "Visitation: Of Christian Painting," 109.

${ }^{6}$ Elizabeth's words become part of the "Ave Maria," and Mary's words in reply to Elizabeth — "My soul doth magnify the Lord" - the opening to the "Magnificat" hymn.

${ }^{7}$ Nancy, "Visitation: Of Christian Painting," 109.

${ }^{8}$ On the "bumps" in this painting see: https://www.spectator.co.uk/2017/06/a-history-of-bumpiconography/.

${ }^{9}$ Nancy, "Visitation: Of Christian Painting." 112.

${ }^{10}$ Nancy, "Visitation: Of Christian Painting," 113. Recent cleaning of the painting might suggest that rather than a round loaf of bread it is a hat that is held here.

11 "And the Word was made flesh and dwelt among us, (and we beheld his glory, the glory as of the only begotten of the Father,) full of grace and truth."

12 Jean-Luc Nancy, "Verbum caro factum," in Dis-Enclosure: The Deconstruction of Christianity, trans. Bettina Bergo, Gabriel Malenfant, and Michael B. Smith (New York: Fordham University Press, 2008), 81-84.

${ }^{13}$ Nancy, "Verbum caro factum," 81-84.

${ }^{14}$ In the original Greek "Eucharist" means "giving thanks": "Take this, and divide it among

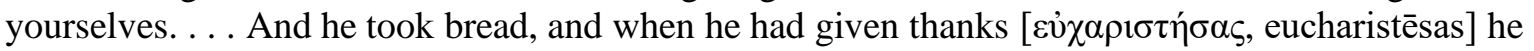
broke it and gave it to them" (Luke 22: 18-19).

${ }^{15}$ In a small 1967 series (four paintings and two drawings), called Still life with altar, McCahon combined a stylised altar with a hovering heart (in red or white) mostly below the altar, presumably signifying the Sacred Heart of Jesus, which is widespread in Catholic symbolism. These same elements carried over to the Visible Mysteries series of the following year (provoked, McCahon said enigmatically, by "things that happened to me in 1967" [Colin McCahon: A Survey Exhibition, (Auckland: Auckland City Art Gallery, 1972), 34]), but with additional elements in some works, such as the chalice in No. 4, and for the most part the heart placed above the altar.

${ }^{16}$ As Peter Simpson notes, McCahon "never joined the Church, though underwent preliminary instruction from the late 1950s, and later did many commissions which required knowledge of Catholic ritual and symbolism which in turn influenced his own practice" (Colin McCahon: Is This the Promised Land? Vol. 2 1960-1987 [Auckland: Auckland University Press, 2020], 91).

${ }^{17}$ See also the accompanying ebook: Working towards Meaning: The Restoration of Colin McCahon's Chapel Windows (Auckland: Auckland Art Gallery Toi o Tāmaki, 2019). Millard Meiss, in a classic article, pointed to a longstanding tradition of theologians and poets who explained the 
mystery of the Incarnation by analogy to the passage of sunlight through a glass window: "Just as the brilliance of the sun fills and penetrates a glass window without damaging it, and pierces its solid form with imperceptible subtlety, neither hurting it when entering nor destroying it when emerging: thus the word of God, the splendor of the Father, entered the virgin chamber and then came forth from the closed womb" ("Light as Form and Symbol in some Fifteenth Century Paintings," The Art Bulletin 27, no. 3 [1945]: 176).

${ }^{18}$ Writing in the catalogue of his 1972 touring Survey exhibition, Colin McCahon said of his 1968 series Visible Mysteries: "I feel that some of this series will eventually be seen as more successful than they might now appear" (Colin McCahon, Colin McCahon: A Survey Exhibition, 34). Certainly, from the perspective of 2020, the Visible Mysteries works seem highly successful: bold, beautiful, resonant and finely resolved.

${ }^{19}$ Of course, the Incarnation is part of a long biblical prophetic tradition including Isaiah's prophecy from the Old Testament: "Behold, a virgin shall conceive and bear a son, and shall call his name Emmanuel," (Isaiah 7: 14). My discussion of prophecy here draws on joint work I have written and published with Rex Butler.

${ }^{20}$ In attempting to answer this question I am again drawing upon Nancy, "Visitation: Of Christian Painting," 122. 